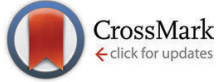

Cite this: Chem. Commun., 2014, 50, 12560

Received 15th July 2014 Accepted 27th August 2014

DOI: $10.1039 / \mathrm{c} 4 \mathrm{cc} 05448 \mathrm{~b}$

www.rsc.org/chemcomm

\section{Co(II)/Co(I) reduction-induced axial histidine- flipping in myoglobin reconstituted with a cobalt tetradehydrocorrin as a methionine synthase model $\dagger$}

\author{
Takashi Hayashi, ${ }^{\star a}$ Yoshitsugu Morita, ${ }^{a}$ Eiichi Mizohata, ${ }^{a}$ Koji Oohora, ${ }^{a}$ \\ Jun Ohbayashi, ${ }^{a}$ Tsuyoshi Inoue ${ }^{a}$ and Yoshio Hisaeda ${ }^{b}$
}

\begin{abstract}
A conjugate between apomyoglobin and cobalt tetradehydrocorrin was prepared to replicate the coordination behavior of cob(I)alamin in methionine synthase. $X$-ray crystallography reveals that the tetracoordinated $\mathrm{Co}_{(1)}$ species is formed through the cleavage of the axial Co-His93 ligation after the reduction of the penta-coordinated Co(II) cofactor in the heme pocket.
\end{abstract}

Methionine synthase, which is widely found in Prokaryota and Eukaryota, is responsible for the methylation of homocysteine to yield methionine. It is known that the enzyme requires $N^{5}$-methyltetrahydrofolate as a methyl group donor and that the methyl group transfer to homocysteine is promoted by a cobalamin cofactor, a vitamin $\mathrm{B}_{12}$-like cobalt corrinoid complex. ${ }^{1-4}$ The entire enzyme structure has a molecular weight of $c a .136 \mathrm{kDa}$ and includes four domains. The complexity of this enzyme system poses significant challenges with respect to the characterization of the entire structure. The crystal structure of the cobalamin-binding domain of methionine synthase has been determined by Ludwig and co-workers, and it was found that the axial ligand of cobalamin is a protein-derived histidine residue and not the benzimidazole moiety of cobalamin. The base-off/His-on coordination state is shown in Fig. 1a. ${ }^{5}$ In the catalytic cycle, two key intermediates have been proposed to exist transiently; (i) a highly nucleophilic tetra-coordinated Co(I) species known as cob(I)alamin and (ii) a methylated Co(III) species known as methylcobalamin. ${ }^{1-3}$ However, the structure of cob(I)alamin has never been determined directly. ${ }^{5,6}$ Herein, we report a hybrid model consisting of a cobalamin model complex with a suitable protein matrix to

\footnotetext{
${ }^{a}$ Department of Applied Chemistry, Graduate School of Engineering, Osaka University, Suita 565-0871, Japan.E-mail: thayashi@chem.eng.osaka-u.ac.jp ${ }^{b}$ Department of Chemistry and Biochemistry, Graduate School of Engineering, Kyushu University, Fukuoka 819-0395, Japan

$\dagger$ Electronic supplementary information (ESI) available: Information on materials, instrumentation, experimental details and additional data on preparation of proteins, spectroscopic measurements and crystal structural analyses. The atomic coordinates and structure factors (PDB codes 3WFT and 3WFU) have been deposited into the Protein Data Bank. See DOI: 10.1039/c4cc05448b
}
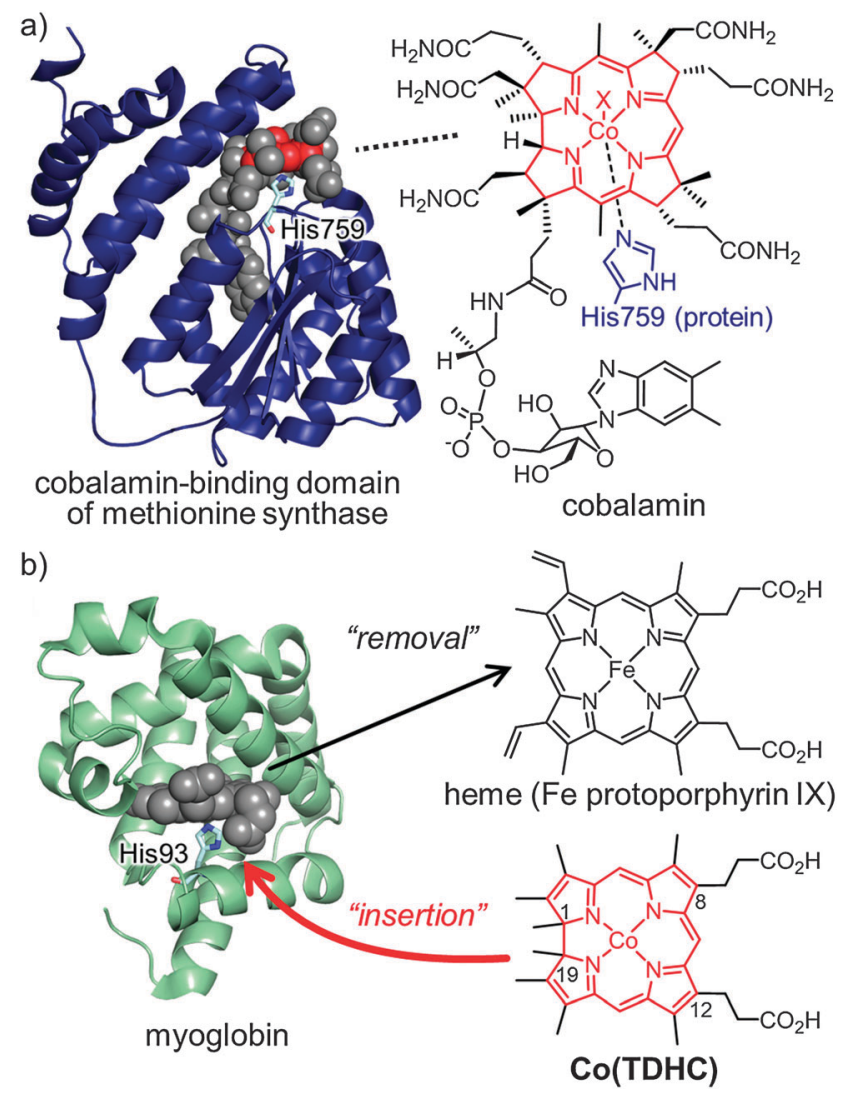

Fig. 1 Structure of holoproteins and cofactors. (a) The crystal structure of the cobalamin-binding domain (PDB: 1BMT) of methionine synthase and the molecular structure of cobalamin. (b) The crystal structure of horse heart myoglobin (PDB: 2V1K) and molecular structures of native heme and Co"(TDHC). Native heme is replaceable with Co"(TDHC) as a cobalamin model.

improve our understanding of the formation of the intermediate with the axial ligand rearrangement in the protein.

The hybrid model for methionine synthase was constructed as follows (Fig. 1b): First, horse heart apomyoglobin was used as a substitute protein matrix for the cobalamin-binding domain of methionine synthase. It is a relatively small and well-known 
protein which provides a histidine residue as an axial ligand to the heme cofactor in the heme-binding pocket as well as the cobalamin-binding domain. Second, a cobalt tetradehydrocorrin complex was designed as an artificial cofactor to mimic the cobalamin moiety because native cobalamin consists of a tetrapyrrole macrocyclic ligand known as a corrinoid. A corrinoid is structurally similar to a porphyrin, except that it lacks one of the four meso carbons which are present in the porphyrin framework. Dolphin and co-workers synthesized a cobalt complex of 1,19-dimethyltetradehydrocorrin and detected the stable $\operatorname{Co}(\mathrm{I})$ species by UV-vis spectroscopy. ${ }^{6}$ This inspired us to insert such a complex into the apomyoglobin heme pocket to obtain ligation by the His93 residue which coordinates to the native heme iron of myoglobin.

The cobalt corrinoid complex, $\mathrm{Co}$ (TDHC) $(\mathrm{TDHC}=8,12-$ dicarboxyethyl-1,2,3,7,13,17,18,19-octamethyltetradehydrocorrin) (Fig. 1b), was prepared as a model of cobalamin by cyclization of the corresponding biladiene- $a, c$ dihydrobromide derivative in the presence of $\mathrm{Co}(\mathrm{OAc})_{2}$ (Scheme S1, ESI $\left.\dagger\right){ }^{7}$ Two methyl substituents at the C1- and C19-positions are on opposite faces of the corrinoid ring and the compound exists as two enantiomers, $(1 R, 19 R)$-TDHC and $(1 S, 19 S)$-TDHC, in a $1: 1$ ratio. The two propionate side chains introduced at the C8- and C12-positions are analogous to those of native heme and are included for the purpose of fixing the cofactor in the proper position via a hydrogen bonding network with polar amino acid residues in the heme pocket. The $\mathrm{Co}^{\mathrm{II}}$ (TDHC) complex was added to apomyoglobin obtained by removal of the heme. ${ }^{8}$ ESI-TOF MS data, the CD spectrum (Fig. S1 and S2, ESI $\dagger$ ) and ICP analysis of the reconstituted protein, $\mathrm{rMb}\left(\mathrm{Co}^{\mathrm{II}}(\mathrm{TDHC})\right)$, were used to confirm that $\mathrm{Co}^{\mathrm{II}}(\mathrm{TDHC})$ binds to the protein in a 1:1 ratio. The UV-vis spectrum of $\mathrm{rMb}\left(\mathrm{Co}^{\mathrm{II}}(\mathrm{TDHC})\right)$ has a sharp absorption band at $510 \mathrm{~nm}$ (Fig. 2a), which is similar to that observed for the $\mathrm{Co}^{\mathrm{II}}$ (TDHC) dimethyl ester in pyridine. ${ }^{9}$ Furthermore, the EPR measurement of $\mathrm{rMb}\left(\mathrm{Co}^{\mathrm{II}}(\mathrm{TDHC})\right)$ indicates a typical spectrum (Fig. 2b): the interaction of the cobalt nucleus $(I=7 / 2)$ with the unpaired electron in a pentacoordinated low-spin $d^{7}$ configuration of Co(II) results in hyperfine splitting of the signal into an octet
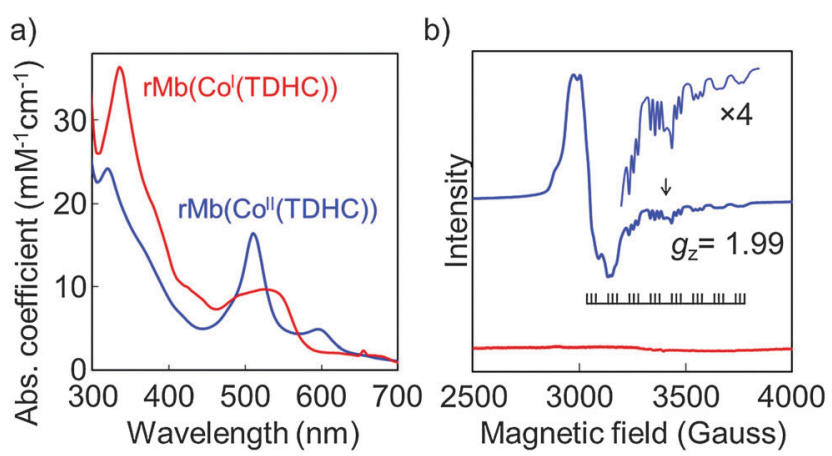

Fig. 2 Characteristic spectra of reconstituted myoglobins: rMb(Co"(TDHC)) (blue) and $\mathrm{rMb}\left(\mathrm{Co}^{\prime}(\mathrm{TDHC})\right.$ ) (red). (a) UV-vis spectra of the reconstituted proteins in $0.1 \mathrm{M}$ potassium phosphate buffer $(\mathrm{pH} 7.0)$ solution at $25^{\circ} \mathrm{C}$. (b) EPR spectra of the reconstituted proteins $(0.5 \mathrm{mM})$ in $0.1 \mathrm{M}$ potassium phosphate buffer $\left(\mathrm{pH}\right.$ 7.0) solution at $10 \mathrm{~K}$. The signal of $g_{x}=g_{y}$ is centered at $g=2.23$. The coupling constants of $\left|A_{\mathrm{Coz}}\right|$ and $\left|A_{\mathrm{Nz}}\right|$ for $\mathrm{rMb}(\mathrm{Co} "(\mathrm{TDHC}))$ are 99.7 and $20.8 \mathrm{G}$, respectively. $\mathrm{rMb}\left(\mathrm{Co}^{\prime}(\mathrm{TDHC})\right)$ is EPR-silent. centered at $g_{z}=1.99$, and the presence of a ${ }^{14} \mathrm{~N}(I=1)$ ligand attached to the axial position of the $\mathrm{Co}^{\mathrm{II}}$ (TDHC) complex shows superhyperfine splitting of each component of the octet into a triplet. ${ }^{5,10}$ This provides support for our proposal that the cobalt atom coordinates to the Nع2-atom of the His93 imidazole ring as an axial ligand. ${ }^{11}$

The crystal structure of $\mathrm{rMb}\left(\mathrm{Co}^{\mathrm{II}}(\mathrm{TDHC})\right)$ was obtained at a resolution of $1.30 \AA$ and reveals that $\mathrm{Co}^{\mathrm{II}}(\mathrm{TDHC})$ is bound in the heme pocket with $\mathrm{Co}(\mathrm{II})-\mathrm{His} 93$ coordination characterized by a Co-N 22 bond length of $2.18 \AA$ (Fig. 3). In the crystals, the ratio of proteins, $\operatorname{rMb}\left(\mathrm{Co}^{\mathrm{II}}((1 R, 19 R)-\mathrm{TDHC})\right)$ and $\mathrm{rMb}\left(\mathrm{Co}^{\mathrm{II}}((1 S, 19 S)-\right.$ TDHC)), was found to be $13: 7$ by the occupancy of the enantiomers (Fig. S3b, ESI $\dagger$ ) because the TDHC ligand provides a mixture of two enantiomers due to introduction of two methyl substituents at the C1- and C19-positions (vide supra). Although the TDHC ligand, whose macrocycle is smaller than that of a porphyrin, has two methyl substituents oriented perpendicularly to the corrin plane, the position of the TDHC framework is remarkably similar to that of the porphyrin framework observed in native myoglobin. As a result, the two propionate side chains located at the C8- and C12-positions are found to participate in hydrogen bonding networks with Lys45 and Ser92/His97, respectively. These residues originally interact with the heme-propionate side chains in myoglobin. In addition, the polypeptide $\mathrm{C} \alpha$ atoms of the native myoglobin and $\mathrm{rMb}\left(\mathrm{Co}^{\mathrm{II}}(\mathrm{TDHC})\right)$ are superimposable with a root-mean-square deviation (RMS value) of $0.223 \AA$ (Fig. S3, ESI $\dagger$ ). ${ }^{12}$ Although there are several examples of hemoproteins reconstituted with artificial porphyrinoid cofactors, ${ }^{8}$ the present work is the first example of incorporation of a metallocorrin derivative into a hemoprotein.

Reduction of $\mathrm{rMb}\left(\mathrm{Co}^{\mathrm{II}}(\mathrm{TDHC})\right)$ upon addition of dithionite under anaerobic conditions leads to UV-vis spectral changes that include clear isosbestic points over $2 \mathrm{~s}$ (Fig. S4, ESI $\dagger$ ). The characteristic
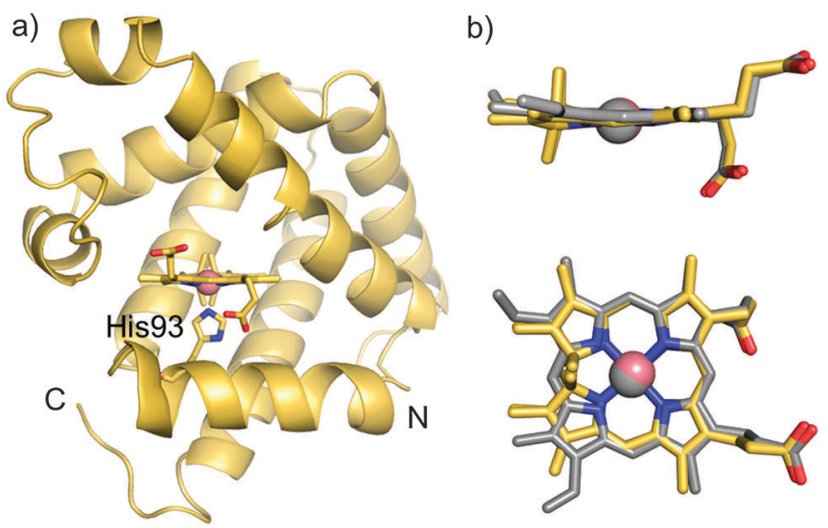

Fig. 3 Crystal structure of $\mathrm{rMb}\left(\mathrm{Co}{ }^{\prime \prime}(\mathrm{TDHC})\right)$. (a) The whole protein structure at a resolution of $1.30 \AA$. Co" (TDHC) and proximal His93 are indicated by stick models. The structure of the TDHC framework possesses two enantiomers with a ratio of $13: 7$ due to the configuration of two methyl substituents at C1- and C19-positions (Fig. 1b). (b) A comparison of the positions of cofactors in the heme pocket of myoglobin. The superimposed structures (top and side views) are obtained from $\mathrm{rMb}$ (Co"(TDHC)) (yellow stick) and native myoglobin (gray stick). The whole protein structures are shown in Fig. S3 (ESI $\dagger$ ). The spheres in the centre of the macrocycles are the cobalt and iron atoms. The structure of native myoglobin is that of $2 \mathrm{~V} 1 \mathrm{~K}$ of the Protein Databank (PDB data). 


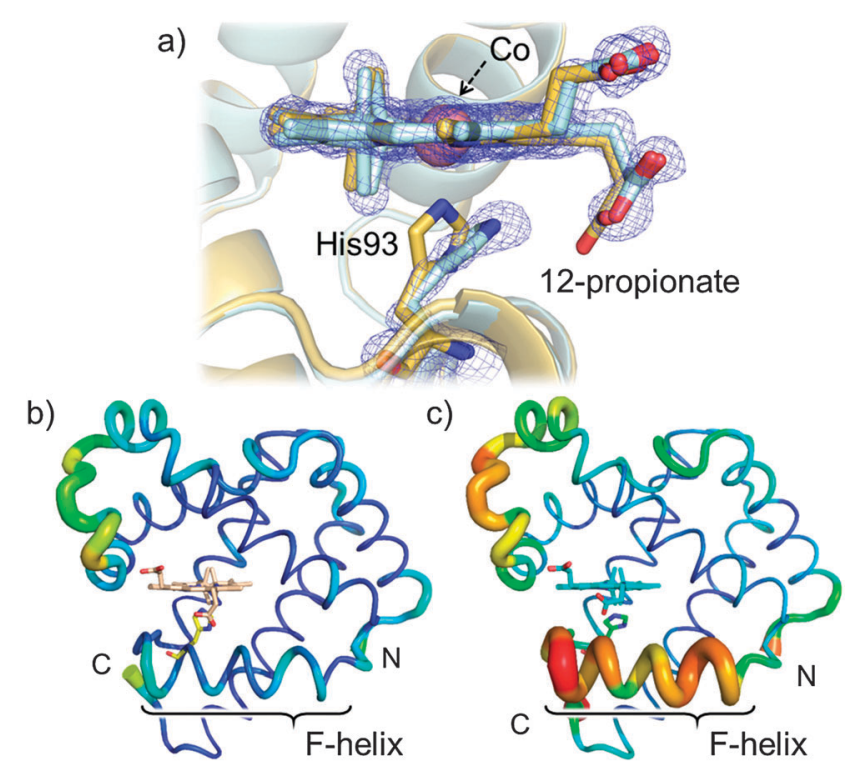

Fig. 4 Crystal structures of two oxidation states of the reconstituted protein. (a) Superimposition of the cofactors and the heme pocket residues of $\mathrm{rMb}\left(\mathrm{Co}^{\prime}(\mathrm{TDHC})\right.$ ) (light blue) and $\mathrm{rMb}\left(\mathrm{Co}^{\prime \prime}(\mathrm{TDHC})\right.$ ) (yellow). The $2 F_{\mathrm{o}}-F_{\mathrm{c}}$ electron density is shown as a blue grid (contoured at $1.0 \sigma$ ) around the His93 residue and the cofactor of $\mathrm{rMb}\left(\mathrm{Co}^{\prime}(\mathrm{TDHC})\right.$ ). (b) and (c) Variations in crystallographic $B$-factors represented as width of the backbone trace in $\mathrm{rMb}\left(\mathrm{Co}^{\prime \prime}(\mathrm{TDHC})\right)$ (left) and $\mathrm{rMb}\left(\mathrm{Co}^{\prime}(\mathrm{TDHC})\right.$ ) (right), respectively.

spectrum of the Co(I) species then appears with an absorption maximum at $530 \mathrm{~nm}$ (Fig. 2a). The disappearance of the characteristic Co(II) low spin EPR signals also indicates the formation of the diamagnetic $d^{8} \mathrm{Co}(\mathrm{I})$ species, $\mathrm{rMb}\left(\mathrm{Co}^{\mathrm{I}}(\mathrm{TDHC})\right)$ (Fig. 2b). At $\mathrm{pH} 7.0$, the $\mathrm{CD}$ spectrum of $\mathrm{rMb}\left(\mathrm{Co}^{\mathrm{I}}(\mathrm{TDHC})\right)$ displays two prominent minima at 209 and $222 \mathrm{~nm}$, which are typical of $\alpha$-helical structures, having the consistent molar ellipticity values with those determined for $\mathrm{rMb}\left(\mathrm{Co}^{\mathrm{II}}(\mathrm{TDHC})\right)$ (Fig. S2, ESI $\dagger)$. The redox potential of $\mathrm{rMb}\left(\mathrm{Co}^{\mathrm{II}}(\mathrm{TDHC})\right) /$ $\operatorname{rMb}\left(\mathrm{Co}^{\mathrm{I}}(\mathrm{TDHC})\right)$ was determined by spectroelectrochemical measurements to be $-0.13 \mathrm{~V} v$ s. SHE at $\mathrm{pH} 7.0$ (Fig. S5, ESI $\dagger$ ), while the value of cobalamin in methionine synthase is $-0.5 \mathrm{~V} .^{13}$ This indicates that $\mathrm{rMb}\left(\mathrm{Co}^{\mathrm{I}}(\mathrm{TDHC})\right)$ is more thermodynamically stable than native $\operatorname{cob}(\mathrm{r})$ alamin in the protein.

To understand the coordination behavior of one of the intermediates, $\operatorname{cob}(\mathrm{I})$ alamin, during the catalytic reaction, the crystals of $\mathrm{rMb}\left(\mathrm{Co}^{\mathrm{II}}(\mathrm{TDHC})\right)$ were directly reduced by soaking in a solution of $0.5 \%(\mathrm{w} / \mathrm{v})$ dithionite, and the resulting spectral changes suggest that the $\operatorname{Co}(\mathrm{I})$ species is formed in the crystal state. The crystal structure of $\mathrm{rMb}\left(\mathrm{Co}^{\mathrm{I}}(\mathrm{TDHC})\right)$ was successfully determined at $1.35 \AA$ A-resolution (Fig. 4a and Fig. S6 and S7, ESI $\dagger$ ). Interestingly, the proximal His93 residue swings out upon cleavage of the Co-His coordination and gains flexibility. In fact, the decreased electron density of the His93 residue is observed in the $2 F_{\mathrm{o}}-F_{\mathrm{c}}$ map $(\sigma=1.0)$. As a result, the distance between the $\mathrm{Co}(\mathrm{I})$ and $\mathrm{N} \varepsilon 2(\mathrm{His} 93)$ atoms is $3.44 \AA$ in the crystal structure of $\mathrm{rMb}\left(\mathrm{Co}^{\mathrm{I}}(\mathrm{TDHC})\right)$. From the crystal structure it was found that $\mathrm{Co}^{\mathrm{I}}(\mathrm{TDHC})$ is bound in the heme pocket as a tetracoordinate complex without axial ligands. This action then induces a steric interaction with the 12-propionate side chain, causing it to deviate from its normal position. Furthermore, in $\operatorname{rMb}\left(\mathrm{Co}^{\mathrm{I}}(\mathrm{TDHC})\right)$, the backbone $B$-factors of the F-helix, ${ }^{14}$ which includes the His93 residue, are found to be remarkably large compared to those of $\mathrm{rMb}\left(\mathrm{Co}^{\mathrm{II}}(\mathrm{TDHC})\right)$ (Fig. $4 \mathrm{~b}$ and $\mathrm{c}$ and Fig. S8, ESI $\dagger$ ) because of the lack of axial ligation. In contrast, the whole protein structure of $\mathrm{rMb}\left(\mathrm{Co}^{\mathrm{I}}(\mathrm{TDHC})\right)$ does not deviate significantly, as indicated by the RMS value of all the C $\alpha$ carbons $(0.204 \AA)$. Additionally, the protein matrix of myoglobin is found to be capable of holding the tetra-coordinate cofactor in the heme pocket via hydrogen bonding and hydrophobic interactions. The $\mathrm{CD}$ spectrum of $\mathrm{rMb}\left(\mathrm{Co}^{\mathrm{I}}(\mathrm{TDHC})\right)$ provides further evidence that the $\alpha$-helicity of the protein is maintained in solution even after release of the axial ligand (vide supra). Taken together, these results indicate that the remarkable structural changes occur locally in the proximal site upon reduction and do not exert a significant influence on the whole structure of the protein. To the best of our knowledge, this is the first example of a tetra-coordinate structure of a $\mathrm{Co}(\mathrm{I})$ species in a corrinoid framework..$^{15}$ It is of particular interest to monitor the unbound form of an axial ligand (His-off) in the myoglobin heme pocket in this unique situation. Our data support the speculation that the species of methionine synthase referred to as "base-off" cobalamin only requires proximal histidine flipping in the process of oxidation/reduction of cobalamin.

In this study, we have designed and prepared myoglobin reconstituted with the cobalt corrinoid complex, $\mathrm{Co}(\mathrm{TDHC})$ as a simple model for the active site of a complicated cobalamindependent methyltransferase. In the heme pocket of myoglobin, $\mathrm{Co}^{\mathrm{II}}$ (TDHC) is tightly bound and provides a model of the baseoff/His-on state which is seen in the cobalamin binding domain of methionine synthase, and then an important intermediate, the tetra-coordinated $\mathrm{Co}(\mathrm{I})$ species, is detectable in the protein matrix. The results described herein provide important insights into understanding how the on/off switching of the axial ligation takes place in the native protein.

This work was supported by Grants-in-Aid for Scientific Research provided by JSPS and MEXT, and the JSPS JapaneseGerman Graduate Externship. Y.M. appreciates support from the JSPS Research Fellowship for Young Scientists. The authors are grateful to the staff of SPring-8 and the staff of Photon Factory for their excellent support during data collection on the BL44XU (SPring-8) and BL-17A (Photon Factory).

\section{Notes and references}

1 B. Kräutler, in Metal Ions in Life Science, ed. A. Sigel, H. Sigel, R. K. O. Sigel, RSC, Cambridge, 2009, ch. 1, vol. 6, pp. 1-51.

2 R. G. Matthews, in Metal Ions in Life Science, ed. A. Sigel, H. Sigel, R. K. O. Sigel, RSC, Cambridge, 2009, ch. 2, vol. 6, pp. 53-113.

3 B. Kräutler, B. Puffer, in Handbook of Porphyrin Science, ed. K. M. Kadish, K. M. Smith, R. Guilard, World Scientific, Singapore, 2012, ch. 117, vol. 25, pp. 131-263.

4 (a) K. L. Brown, Chem. Rev., 2005, 105, 2075-2149; (b) R. Banerjee, C. Gherasim and D. Padovani, Curr. Opin. Chem. Biol., 2009, 13, 484-491; (c) K. Gruber, B. Puffer and B. Kräutler, Chem. Soc. Rev., 2001, 40, 4346-4363; (d) R. G. Matthews, Acc. Chem. Res., 2001, 34, 681-689; (e) Y. Kung, N. Ando, T. I. Doukov, L. C. Blasiak, G. Bender, J. Seravalli, S. W. Ragsdale and C. L. Drennan, Nature, 2012, 484, 265-269; $(f)$ C. H. Hagemeier, M. Krüer, R. K. Thauer, E. Warkentin and U. Ermler, Proc. Natl. Acad. Sci. U. S. A., 2006, 103, 18917-18922. 
5 C. L. Drennan, S. Huang, J. T. Drummond, R. G. Matthews and M. L. Ludwig, Science, 1994, 266, 1669-1674.

6 C.-J. Liu, A. Thompson and D. Dolphin, J. Inorg. Biochem., 2001, 83, 133-138.

7 D. Dolphin, R. L. N. Harris, J. L. Huppatz, A. W. Johnson and I. T. Kay, J. Chem. Soc. C, 1966, 30-40.

8 T. Hayashi, in Handbook of Porphyrin Science, ed. K. M. Kadish, K. M. Smith, R. Guilard, World Scientific, Singapore, 2010, ch. 23, vol. 5, pp. 1-69.

9 Y. Murakami and Y. Aoyama, Bull. Chem. Soc. Jpn., 1976, 43, 683-688. 10 (a) S. A. Cockle, H. A. O. Hill, J. M. Pratt and R. J. P. Williams, Biochim. Biophys. Acta, 1969, 177, 686-688; (b) Y. Murakami, Y. Hisaeda and A. Kajihara, Bull. Chem. Soc. Jpn., 1983, 56, 3642-3646.
11 N. S. Hush and I. S. Woolsey, J. Chem. Soc., Dalton Trans., 1974, 24-34. 12 H.-P. Hersleth, T. Uchida, A. K. Røhr, T. Teschner, V. Schünemann, T. Kitagawa, A. X. Trautwein, C. H. Görbitz and K. K. Andersson, J. Biol. Chem., 2007, 282, 23372-23386.

13 R. V. Banerjee, S. R. Harder, S. W. Ragsdale and R. G. Matthews, Biochemistry, 1990, 29, 1129-1135.

14 (a) P. Picotti, A. Marabotti, A. Negro, V. Musi, B. Spolaore, M. Zambonin and A. Fontana, Protein Sci., 2004, 13, 1572-1585; (b) C. Nishimura, H. J. Dyson and P. E. Wright, J. Mol. Biol., 2011, 411, 248-263.

15 (a) P. Engel, G. Rytz, L. Walder, U. Vögeli and R. Scheffold, in Vitamin $B_{12}$, ed. B. Zagalak and W. Friedrich, Walter de Gruyter \& Co., Berlin, 1979, pp. 171-172; (b) P. Doppelt, J. Fischer and R. Weiss, Inorg. Chem., 1984, 23, 2958-2962. 